[計 測 自 動制 御 学 会 論文集]

[ Vol.48, No.5, 249/256 (2012) ]

\title{
複雑ネットワークを用いた複数競合サービスの普及に関する研究 一消費者効用の非均質性の影響一
}

\author{
藤 井 信 忠*·貝 原 俊 也*·吉 川 智 哉*
}

\author{
A Study on Diffusion of Plural Competing Services in Complex Networks \\ - Influence of Heterogeneity of Consumer Utility—
}

Nobutada FuJi**, Toshiya KaIHARA* and Tomoya YoshiKawA*

\begin{abstract}
Service quality is often unstable because of the nature of service delivery systems involving humans. Furthermore, consumers cannot confirm the quality of service before purchase because service has no shape. For these reason, good service does not always diffuse. Therefore, it is necessary to study diffusion of service by computer simulations to clarify the process of acceptance among consumers. This paper presents a multiagent-based model for diffusion of plural services including heterogeneity of consumer utility in complex networks. It is verified that the heterogeneity of consumer utility and network structure affect service diffusion process in the results of computer simulations. In the result, it is revealed that the service that consumer utility is more heterogeneous wins in the competition in the market, but the diffusion rate lowers.
\end{abstract}

Key Words: service diffusion, heterogeneity of utility, complex networks

\section{1. 緒言}

近年, サービス産業は日本経済の 7 割近く $(\mathrm{GDP} \cdot$ 雇用 ベース）を占める重要な産業となっている.ささらに, 少子高齢 化など社会構造の変化に対応したサービス需要の増大, 製造 業を中心に業務のモジュール化が進むことによるアウトソー シングの拡大，公的市場の民間開放や規制緩和による新たな サービス市場の拡大などを背景に, 今後もサービス産業の重 要性は高まっていくと考えられる ${ }^{1)}$.

それに応じてサービスに関する研究の重要性も高まってお り, 従来のマーケティング分野のみならず, 工学分野におい ても Product-Service System (PSS) ${ }^{2)}$ やサービス・サイエ ンス ${ }^{3)}$ な゙の研究が始められている，日本においても，サー ビス工学 ${ }^{4)}$ に関する研究が進められており, 製造業で培って きた科学的・工学的手法を活かしたサービスの解析・設計を 中心に研究が行なわれている。 しかし品質の良いサービスが 開発されたとしても, サービスは無形で品質を事前に確認す ることが難しいために, 消費者に情報が行き渡らずに普及が うまく進まないことも起こりうる. そのため, サービスの設 計論のみならず, サービスの普及に関する研究も必要である. サービスは, 無形性, 同時性, 非均質性, 消滅性など, 製造業

* 神戸大学大学院システム情報学研究科 神戸市灘区六甲台町 1-1

* Graduate School of System Informatics, Kobe University, 1-1 Rokkodaicho, Nada-ku, Kobe

(Received February 1, 2011)

(Revised September 26, 2011)
とは異なる特性を有している ${ }^{5)}$ 。これらの特性による消費者へ の影響として, 非均質性などによりサービスを利用した際に提 供される品質は一定でなかったり，無形性により購入前にサー ビス品質を把握できないなどの影響が考えられる，そこで本 研究では利用前の期待を期待効用, 利用して実際に得る効用を 事後効用とし，これらを消費者のサービスに対する効用と考え る.そしてサービスの特徵としてこれらの消費者効用が非均 質であることに着目し, サービスの普及に関する研究を行なう.

またサービスは製品に比べると広告だけでは十分な情報伝 達が難しく，クチコミなどの消費者の対人コミュニケーショ ンが重要であるため ${ }^{6)}$, サービスの普及について考える場合, 消費者間のコミュニケーションについても考慮する必要があ る。そのような普及に影響を及ぼす消費者間の相互作用のひ とつとして外部性がある，外部性とは，ある経済主体の行動 が市場を通さずに別の経済主体に対して影響を与えるという ものであり, クチコミや流行などの消費者コミュニケーショ ンもその一例である．外部性に関する先行研究として Katz らが，利用者が多ければ多いほど得られる効用が増すネット ワーク外部性に着目し，ネットワーク外部性を有する製品の 効用に関する定式化と市場のモデル化を行なった ${ }^{7)}$. しかし Katz らの市場モデルは消費者個人が市場全体の購入者数を 把握しているという非現実的なモデルとなっていた。 そこで 消費者をエージェントとしてマルチエージェントシステムに よって市場をモデル化し，そのエージェント間の知人関係の ネットワークを複雑ネットワークによって表現することで, 消 費者は自分の周りの情報しか得られないような市場モデルも 
提案されている ${ }^{8)}$. さらに複雑ネットワークで消費者のつな がりを表現した市場モデルに消費者の異質性を導入し, 普及 に与える影響について検証する研究も行なわれている ${ }^{9), 10)}$. しかしこれらの研究は対象を製品としたものが多く，製品と サービスの違いやサービスの特性による影響についてはあま り考慮されていない.

そこで本研究ではサービスの特性が消費者に与える影響に 着目し, サービスの特性が普及にどのような影響を与えるか を明らかにすることを目的とする。そのために製品を対象と したマルチエージェントシステムと複雑ネットワークを用い た市場モデル9),10)を基に，サービスの特性による消費者へ の影響として消費者効用の非均質性を導入し, サービスの普 及について検証を行なう。これまで，一度契約すると継続的 に利用し続け再選択不可能なサービスを対象として，単一の サービスに対する普及特性を検証してきた ${ }^{11)}$ ，しかし市場に おけるサービスの普及は複数の企業が競合しながら進む場合 が多いため，本稿では複数のサービスが競合する市場に着目 し，定式化の拡張を行なうとともにサービスの特性による消 費者効用の非均質性が普及に与える影響を検証する。

\section{2. 提案手法のモデル化}

\section{1 消費者エージェントのモデル化}

サービスは無形であるために購入後に手元に残らず繰り返 し利用するようなものが多いが，本稿ではインターネットの プロバイダのように, 複数のうちから 1 つを選択し一度契約 すると継続的に利用し続けるようなサービスを対象とする.

提案手法のモデル化は川村らのモデル ${ }^{8)}$ を参照して行なっ た. 本稿に㧍ける普及モデルは, 市場に少数の初期購入者が いるところからシミュレーションを開始し，外部性の影響に よって購入者が増えていき, シミュレーション終了時の購入 者の割合を市場における普及率とするモデルである.

消費者エージェント $i$ はシミュレーションステップ $t$ にお いて, サービス $m$ に対する効用 $U_{i m}(t)$ と閾值 $T_{i m}$ が以下 の条件を満たした場合サービス $m$ の購入を行なうものとす る.ただし複数のサービスが同時に条件を満たした場合，効 用 $U_{i m}(t)$ の高いほうを購入する.

$$
U_{i m}(t) \geq T_{i m}
$$

効用 $U_{i m}(t)$ については以下のように定義する.

$$
U_{i m}(t)=R_{i m}(t)+\sum_{j \in N \backslash\{i\}} g_{j m}(t) y_{i m}^{j}(t),
$$

ここで $R_{i m}(t)$ はエージェント $i$ が単独でサービス $m$ から 得る効用を, $y_{i m}^{j}(t)$ は自分以外の他のエージェント $j$ から得 る外部性の効果を, $N$ は消費者エージェントの集合を表わす. また購入していないエージェントからは外部性の効果を受け ないよう $g_{j m}(t)$ を以下のように定義する.

$$
g_{j m}(t)= \begin{cases}1, & \text { if } j \text { is using service } m \\ 0, & \text { otherwise }\end{cases}
$$

エージェント $i$ が単独で得る効用 $R_{i m}(t)$ は, 購入前のサー ビスへの期待効用 $R_{i m}^{e x p}$ と, 購入して実際に得られる事後効 用 $R_{i m}^{a c t}$ とに分けて考え，以下のように定義する.

$$
R_{i m}(t)= \begin{cases}R_{i m}^{a c t}, & \text { if } i \text { is using service } m \\ R_{i m}^{e x p}, & \text { otherwise }\end{cases}
$$

本稿ではこれらの効用を用いて，無形性などのために利用 前に品質を把握できず期待効用が非均質となること，サービ 又提供者の能力の非均質性などのために利用して得られる事 後効用が非均質となることを，サービスの特性による消費者 効用の非均質性として表現する，具体的には，期待効用，事 後効用を以下のように消費者ごとに正規分布に基づいて設定 し，標準偏差の值を変えることで，消費者効用の非均質性を モデル化している.

$$
\begin{aligned}
R_{i m}^{e x p} & =N\left(\alpha, \beta_{e}\right) \\
R_{i m}^{a c t} & =N\left(\alpha, \beta_{a}\right)
\end{aligned}
$$

またステップ $t$ においてエージェント $i$ が他のエージェン ト $j$ から得る外部性の効果 $y_{i m}^{j}(t)$ は, 以下のように定義する. 式中の各項は後に詳述するが，事後効用と期待効用の差に基 づく満足度のみではなく，事後効用との和として外部性の効 果をモデル化したのは，サービスの利用後に得られる効用そ のものの大きさも外部性の要因であると考えたからである.

$$
\begin{aligned}
y_{i m}^{j}(t) & =\left(R_{j m}^{a c t}+S_{j m}(t)\right) w_{i j} \\
& +\left(R_{j m}^{a c t}+S_{j m}(t)\right) \sum_{x \in N \backslash\{i, j\}} w_{i x} w_{x j} \\
& +\left(R_{j m}^{a c t}+S_{j m}(t)\right) \sum_{x, y \in N \backslash\{i, j\}, x \neq y} w_{i x} w_{x y} w_{y j}
\end{aligned}
$$

ここで $w_{i j}$ はつながりをもつ消費者間の親密度を表わし， 以下のように表わす.

$$
\begin{cases}w_{i j}>0, & \text { if } i \text { and } j \text { are friends } \\ w_{i j}=0, & \text { otherwise }\end{cases}
$$

$$
\text { subject to } \sum_{j \in N_{i}} w_{i j}=1
$$

この親密度の定義より，(8) 式において 2 人のエージェン 卜を介した 3 次のつながり以降の効果は微小となるため，(8) 式は 3 次のつながりによる効果までを考慮している ${ }^{8)}$.

また $S_{j m}(t)$ は消費者エージェント $j$ のサービス $m$ に対す る満足度を表わす，消費者は購入したサービスの価值をサー ビスに見込んだ期待を基に評価しており, 購入を行なったエー ジェント $i$ は期待効用と事後効用とのギャップに基づいて満 足度 $S_{i m}(t)$ を得る。満足度 $S_{i m}(t)$ は，プロスペクト理論に 基づく吉光らの研究 ${ }^{12)}$ を参照し，正のギャップによる満足よ りも，負のギャップによる不満足の影響のほうが大きいもの として，以下のように定義する.

$$
S_{i m}(t)= \begin{cases}f\left(R_{i m}^{e x p}, R_{i m}^{a c t}\right), & \text { if } i \text { use service } m \\ 0, & \text { otherwise }\end{cases}
$$




$$
f\left(R_{i m}^{e x p}, R_{i m}^{a c t}\right)=\left\{\begin{array}{c}
a^{+}\left\{1-e^{-\frac{b^{+}}{a^{+}}\left(R_{i m}^{a c t}-R_{i m}^{e x p}\right)}\right\}, \\
\left(R_{i m}^{a c t} \geq R_{i m}^{e x p}\right) \\
a^{-}\left\{1-e^{-\frac{b^{-}}{a^{-}}\left(-R_{i m}^{a c c}+R_{i m}^{e x p}\right)}\right\} \\
\left(R_{i m}^{a c t}<R_{i m}^{e x p}\right)
\end{array}\right.
$$

ここで $a^{+}, a^{-}$は関数の収束する值を $, b^{+}, b^{-}$は参照点 におけるグラフの傾きを表わす.

\section{2 消費者ネットワークのモデル化}

本稿に扮ける普及モデルでは，消費者は周囲の購入者から 外部性の効果を受けて購入し, 普及が進む. その際に外部性 が伝わっていく消費者間のネットワークは，複雑ネットワー クを用いて表現する。複雑ネットワークとは，インターネッ トなどの情報通信技術のネットワークだけでなく, 友人関係 のような社会ネットワークや神経ネットワークのような生体 ネットワークなど, 現実に存在する複雑なネットワーク全般 を指す ${ }^{13)}$.

複雑ネットワークに関する研究では, ネットワーク構造の 性質を表わす指標として以下の 3 つが用いられる.

-次数 $k$ : ある頂点 $i$ の次数 $k_{i}$ とは, 頂点 $i$ につながって いる辺の数のことである.

- 平均頂点間距離 $L$ : ある頂点 $i$ から別の頂点 $j$ に行くた めに通らなければならない辺の最小の本数を $d_{i j}$, ネット ワークのすべての頂点の数を $N$ としたとき, 頂点 $i$ の平均 頂点間距離 $L_{i}$ とは任意の 2 頂点間 $i, j(i \neq j)$ の距離 $d_{i j}$ の平均であり，(12) 式のように表わされる.

$$
L_{i}=\frac{1}{N-1} \sum_{i \neq j} d_{i j}
$$

そしてネットワーク全体の平均頂点間距離 $L$ とは, (13) 式のようにすべての頂点の平均頂点間距離の平均で表わさ れる。

$$
L=\frac{1}{N} \sum_{i=1}^{N} L_{i}
$$

・クラス夕係数 $C$ : クラスタ係数とはネットワークのグルー プ化の度合いを表わす指標で，ある頂点とつながっている 2 つの頂点もまた直接つながっている割合のことをいう。

頂点 $i$ のクラス夕係数 $C_{i}$ は, $k_{i}$ 個の $i$ に隣接する頂点 のうち直接つながっているぺアの数を $E_{i}$ とすると，(14) 式のように表わされる.

$$
C_{i}=\frac{E_{i}}{k_{i} C_{2}}
$$

そしてネットワークのクラスタ係数 $C$ とは, (15) 式の ようにすべての頂点のクラス夕係数の平均で表わされる.

$$
C=\frac{1}{N} \sum_{i=1}^{N} C_{i}
$$

本稿では複雑ネットワーク研究における代表的なネットワー クモデルを用いて, ネットワーク構造の頂点を消費者エージェ ント, 辺をエージェント間のつながりとして, 消費者同士のつ
ながりを表現する，使用したネットワークモデルは，Fig. 1 の (a) Regular モデル, (b) Random モデル ${ }^{14)}$, (c) WS モ デル ${ }^{15)}$, (d) BA モデル ${ }^{16)}$, (e) KE-1 モデル 17), (f) KE-2 モデル ${ }^{18)}$ の 6 つである。これらのモデルは複雑ネットワーク 研究で社会ネットワークなどの分析から得られた特徵を表現 するために提案されたモデルであり，実際の社会ネットワー クに近い特徵をもっている。構造の異なる複数のモデルを用 いて実験を行ない結果を比較することで，ネットワーク構造 のもつ特徴が普及に与える影響についても明らかにすること を目指している。

以下にこれらのモデルについて説明する.

(a) Regular モデル

Regular モデルは, 自分の近隣の人とリンクをもつように 定義された構造が最も単純な相互作用ネットワークの 1 つ である．地理的要因を考慮した社会ネットワークをモデル 化する場合などに使用される，格子状のネットワークであ るためクラス夕係数 $C$ が大きく, 平均頂点間距離 $L$ も大 きい.

(b) Random モデル

あらかじめ決められた辺の数に基づいて消費者エージェン ト同士がランダムに結合された相互作用ネットワーク．明 示的にネットワーク構造を取りあげていない研究や論理的 解析を試みる研究で用いられることが多い. 平均頂点間距 離 $L$ が小さく, クラスタ係数 $C$ も小さい.

(c) WS モデル

Regular モデルと Random モデルの中間の特徴をもった モデルで，スモールワールドモデルとも呼ばれる。ネット ワーク構造が Regular モデルに比較的似ているためクラス 夕係数 $C$ が大きいが，ショートカットと呼ばれる辺によっ て平均頂点間距離 $L$ が小さくなっている.

(d) BA モデル

次数分布がベき乗分布に従うモデルで，非常に高い次数を もつハブが存在するネットワークモデルである．インター ネットなどのモデル化に使用される. 平均頂点間距離 $L$ が 小さく, クラスタ係数 $C$ も小さい.

(e) KE-1 モデル

$\mathrm{BA}$ モデルの拡張モデルの 1 つで, 次数分布がべき乗分布 に従いながら，近隣同士のつながりが多いネットワークモ デル. 平均頂点間距離 $L$ が大きく, クラス夕係数 $C$ も大 きい。

(f) KE-2 モデル

KE-1 モデルを改良したモデルで, KE-1 モデルにショート カットが存在するネットワーク構造をもつ. 次数分布がべ き乗分布に従い, 平均頂点間距離 $L$ が小さく, クラス夕係 数 $C$ が大きい.

それぞれのネットワークモデルを頂点の数を 1000, 平均次 数を 6 として構築すると, 各ネットワークにおけるネットワー クの性質を表わす指標はそれぞれ Table 1 のようになる. 


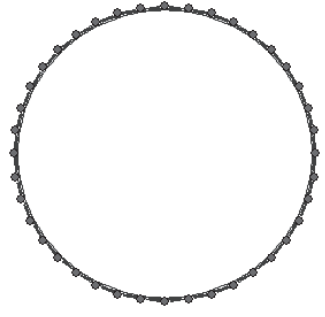

(a) Regular model

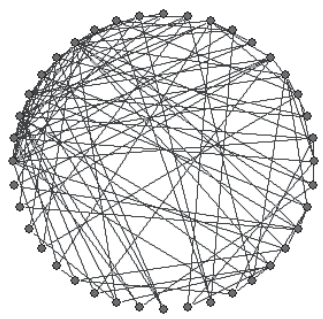

(d) BA model

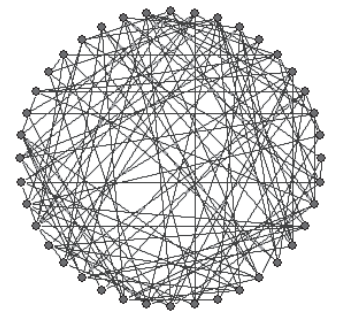

(b) Random model

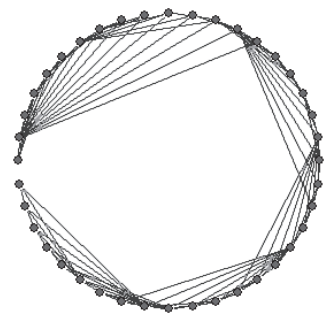

(e) KE-1 model

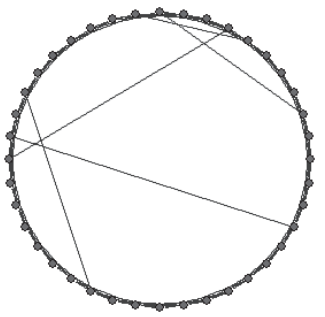

(c) WS model

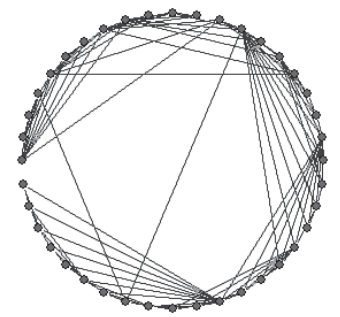

(f) KE-2 model

Fig. 1 Network models

Table 1 Network model features

\begin{tabular}{|c|c|c|c|}
\hline & Average distance $L$ & Clustering coefficients $C$ & Degree distribution \\
\hline Regular model & 83.8 & 0.60 & Constant \\
\hline Random model & 4.09 & 0.0061 & Normal distribution \\
\hline WS model & 7.81 & 0.52 & Normal distribution \\
\hline BA model & 3.47 & 0.036 & Power-law distribution \\
\hline KE-1 model & 29.7 & 0.71 & Power-law distribution \\
\hline KE-2 model & 5.73 & 0.64 & Power-law distribution \\
\hline
\end{tabular}

\section{3. 計算機実験}

\section{1 実験条件}

前章の消費者エージェントモデルとネットワークモデルを 用いて，サービスの普及過程に関する計算機実験を行なった。

消費者エージェント数を 1000 , 平均次数を 6 とし， 2 種類 のサービスが競合する市場モデルを構築した。エージェント の各サービスへの閾值は等しいものとし，(1) 式における閾值 $T_{i m}$ は一様分布 $U(3,6)$ に基づいて設定した．満足度 $S_{i m}(t)$ については，期待効用と事後効用のギャップが -3 のときに 満足度が -3 となるように満足度関数 (11) 式の $a^{+}, a^{-}, b^{+}$, $b^{-}$を設定した。また先行研究 $\left.{ }^{12}\right) に$ 基づいて正の満足度は負 の満足度の半分の值になるように設定している．実験の初期 状態における各サービスの購入者数は, Rogers の普及理論 ${ }^{19)}$ に基づき全体の $2.5 \%$ とした。シミュレーションの終了条件 については，シミュレーションステップが進んでも購入者の 数が増えなくなった時点でシミュレーションを終了させるも のとする。

この条件下で, 本稿では消費者効用の非均質性による普及へ の影響を検証するために，二つの実験を行なった。まず実験 1 では，市場において競合するサービス同士は似た性質をもっ ていることが多いと考えられるため，似た性質をもつサービ ス同士が競合する市場を想定して各サービスの消費者効用を
Table 2 Experimental condition 1

\begin{tabular}{|l|c|c|c|c|}
\hline & \multicolumn{2}{|c|}{ Service 1 } & \multicolumn{2}{c|}{ Service 2 } \\
\hline & $R_{i 1}^{\text {exp }}$ & $R_{i 1}^{a c t}$ & $R_{i 2}^{\text {exp }}$ & $R_{i 2}^{a c t}$ \\
\hline condition 1 & 3 & 3 & 3 & 3 \\
\hline condition 2 & $N\left(3,0.5^{2}\right)$ & $N\left(3,0.5^{2}\right)$ & $N\left(3,0.5^{2}\right)$ & $N\left(3,0.5^{2}\right)$ \\
\hline condition 3 & $N\left(3,1^{2}\right)$ & $N\left(3,1^{2}\right)$ & $N\left(3,1^{2}\right)$ & $N\left(3,1^{2}\right)$ \\
\hline
\end{tabular}

Table 3 Experimental condition 2

\begin{tabular}{|l|c|c|c|c|}
\hline & \multicolumn{2}{|c|}{ Service 1 } & \multicolumn{2}{c|}{ Service 2 } \\
\hline & $R_{i 1}^{\text {exp }}$ & $R_{i 1}^{a c t}$ & $R_{i 2}^{\text {exp }}$ & $R_{i 2}^{a c t}$ \\
\hline condition 4 & 3 & 3 & $N\left(3,0.5^{2}\right)$ & $N\left(3,0.5^{2}\right)$ \\
\hline condition 5 & 3 & 3 & $N\left(3,1^{2}\right)$ & $N\left(3,1^{2}\right)$ \\
\hline condition 6 & $N\left(3,0.5^{2}\right)$ & $N\left(3,0.5^{2}\right)$ & $N\left(3,1^{2}\right)$ & $N\left(3,1^{2}\right)$ \\
\hline
\end{tabular}

同じ条件とした。これはたとえば教育・学習支援業において， 学習塾同士のように同じサービス同士が競合する場合を想定 している. (5)(6) 式の期待効用・事後効用については Table 2 の条件 1 3の 3 通りの条件でシミュレーションを行ない, 結果を比較した。条件 1 は消費者効用が均質で，条件 2 ，条 件 3 は消費者効用が非均質となる。また条件 2 と条件 3 で は，条件 3 のほうが消費者効用のばらつきが大きく，非均質 性が大きくなる.

それに対して実験 2 では，各サービスの消費者効用の非均 質性の大きさが異なる条件でシミュレーションを行なった。 これはたとえば教育・学習支援業において，講師が授業を行 
Table 4 Experimental result 1

\begin{tabular}{|c|c|c|c|c|c|c|c|}
\hline \multicolumn{2}{|c|}{ Network } & Regular & Random & WS & BA & KE-1 & KE-2 \\
\hline \multirow{3}{*}{ condition 1 } & Service 1 & 43.07 & 50.07 & 49.39 & 51.45 & 39.83 & 45.07 \\
\cline { 2 - 8 } & Service 2 & 42.78 & 49.91 & 48.24 & 48.54 & 38.47 & 47.42 \\
\cline { 2 - 8 } & Total & 85.85 & 99.98 & 97.63 & 99.99 & 78.30 & 92.48 \\
\hline \hline \multirow{3}{*}{ condition 2 } & Service 1 & 39.25 & 49.02 & 45.07 & 48.57 & 39.56 & 43.64 \\
\cline { 2 - 8 } & Service 2 & 40.29 & 49.86 & 44.71 & 50.61 & 38.54 & 42.56 \\
\cline { 2 - 8 } condition 3 & Total & 79.55 & 98.87 & 89.78 & 99.18 & 78.10 & 86.20 \\
\hline \hline & Service 1 & 34.62 & 43.69 & 36.27 & 46.27 & 34.17 & 35.97 \\
\cline { 2 - 8 } & Service 2 & 34.26 & 45.52 & 37.48 & 43.68 & 35.06 & 36.95 \\
\cline { 2 - 8 } & Total & 68.88 & 89.21 & 73.75 & 89.95 & 69.23 & 72.92 \\
\hline
\end{tabular}

Table 5 Experimental result 2

\begin{tabular}{|c|c|c|c|c|c|c|c|}
\hline \multicolumn{2}{|c|}{ Network } & Regular & Random & WS & BA & KE-1 & KE-2 \\
\hline \multirow{3}{*}{ condition 4 4} & Service 1 & 34.63 & 32.86 & 38.43 & 39.09 & 31.13 & 35.13 \\
\cline { 2 - 8 } & Service 2 & 48.09 & 66.91 & 55.39 & 60.75 & 49.63 & 54.30 \\
\cline { 2 - 8 } & Total & 82.72 & 99.77 & 93.81 & 99.84 & 80.76 & 89.43 \\
\hline \hline \multirow{3}{*}{ condition 5 } & Service 1 & 26.55 & 24.83 & 29.71 & 32.53 & 24.85 & 26.92 \\
\cline { 2 - 8 } & Service 2 & 47.59 & 72.33 & 53.49 & 65.03 & 48.66 & 53.64 \\
\cline { 2 - 8 } & Total & 74.15 & 97.17 & 83.2 & 97.55 & 73.51 & 80.56 \\
\hline \hline \multirow{3}{*}{ condition 6 } & Service 1 & 29.76 & 34.84 & 33.09 & 39.50 & 30.69 & 31.18 \\
\cline { 2 - 8 } & Service 2 & 41.47 & 60.39 & 46.02 & 56.17 & 42.58 & 46.28 \\
\cline { 2 - 8 } & Total & 71.23 & 95.23 & 79.11 & 95.66 & 73.26 & 77.45 \\
\hline
\end{tabular}

なう集団学習の学習塾に比べて, 個別指導塾や家庭教師は個 別に指導を行なうため得られる効用のばらつきが大きいよう に，競合するサービス間で消費者効用のばらつきの大きさが 異なる場合を想定している. 実験 2 では各サービスの期待効 用・事後効用 $((5)$ (6) 式) を Table 3 の条件 4 6 の 3 通り の条件で与えシミュレーションを行なった，条件 4 は消費者 効用が均質であるサービス 1 と非均質性が小さいサービス 2 が競合する条件, 条件 5 は消費者効用が均質であるサービス 1 と非均質性が大きいサービス 2 が競合する条件, 条件 6 は 消費者効用の非均質性が小さいサービス 1 と非均質性が大き いサービス 2 の競合する条件となっている，なお，消費者効 用が非均質な場合も期待効用と事後効用のばらつき度合いは (5)，(6) 式に示したとおり別々に設定できるが，本稿では簡 単化のため同じに設定している.

\section{2 実験結果とネットワーク構造に関する考察}

実験 1 , 実験 2 の各条件における各サービスの 100 試行の 平均普及率はそれぞれ Table 4, Table 5 のようになった.

条件 1 6 においてネットワークモデルごとのネットワー ク全体の普及率を比較すると, ネットワークモデルの平均頂 点間距離 $L$ とクラスタ係数 $C$ の特徵に基づいた傾向が見ら れた. どの条件においても, 平均頂点間距離 $L$ とクラス夕係 数 $C$ が小さい Random, BA モデルは他のモデルに比べて 普及率が高く, 続いて平均頂点間距離 $L$ が小さくクラス夕係 数 $C$ が大きい WS, KE-2 モデル, そして平均頂点間距離 $L$ とクラスタ係数 $C$ が大きい Regular, KE-1 モデルはほかの モデルに比べ普及率が低くなっていた. 平均頂点間距離 $L$ が 小さいネットワークでは, 外部性の効果がネットワーク全体 に伝わりやすいため, Random, BA, WS, KE-2 モデルは Regular, KE-1 モデルに比べ普及率が高くなったと考えられ
る.またクラスタ係数 $C$ が大きいネットワークモデルはクラ ス夕同士が連結した構造をもち, クラスタを通じて徐々に購 入が広がっていくため，あるクラス夕で購入が止まるとその 先のクラスタに普及しなくなる，そのため，平均頂点間距離 $L$ の小さい Random, WS, BA, KE-2 モデルの中でも WS, KE-2 モデルは Random, BA モデルに比べて普及率が低く なっていたと考えられる。

また, Fig. 2 は条件 1 における 100 回の各試行のサービ ス 1 とサービス 2 の普及率の差のグラフである. グラフの横 軸は試行番号を, 縦軸は普及率の差（サービス 1 の普及率 サービス 2 の普及率) を表わしている. Fig. 2 から, 条件 1 に掞いて両サービスの平均普及率には差はないが, 各試行の 結果を見るとサービス $1 ， 2$ の普及率に差が見られ，その差 の大きさはネットワークモデルによって異なることがわかっ た. 平均頂点間距離 $L$ とクラス夕係数 $C$ が小さい Random (Fig. 2(c)), BA (Fig. 2(d)) モデルでは, 外部性の影響がネッ トワーク全体に一気に広がりやすいモデルであるため, 売れて いるサービスが外部性の影響でさらに売れるというポジティ ブ・フィードバックが強く働き, 一方のサービスが大勝すると いうケースが見られ, Regular (Fig. 2(a)), KE-1 (Fig.2 (b)), WS (Fig. $2(\mathrm{e})$ ), KE-2 (Fig. 2 (f)) モデルに比べて各試行の 普及率の差が大きくなっていた．また Regular, KE-1, WS, $\mathrm{KE}-2$ モデルの中でも, KE-1, WS, KE-2 モデルはネット ワーク構造にショートカットやハブを有しており，それらの 消費者が購入したほうのサービスは競合において有利になる. そのためショートカットやハブが存在しない Regular モデ ルに比べ, 各試行の普及率の差が大きくなっていたと考えら れる。 


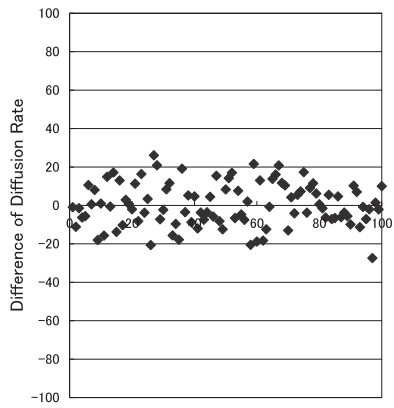

(a) Regular model

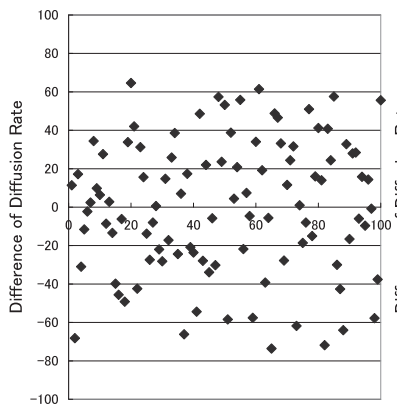

(c) Random model

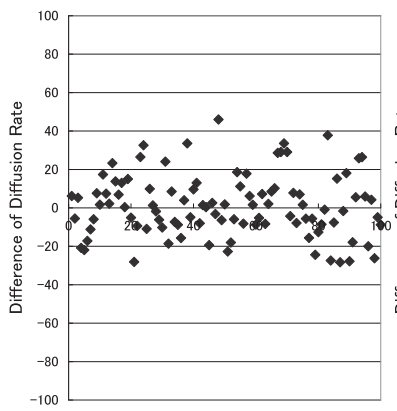

(e) WS model

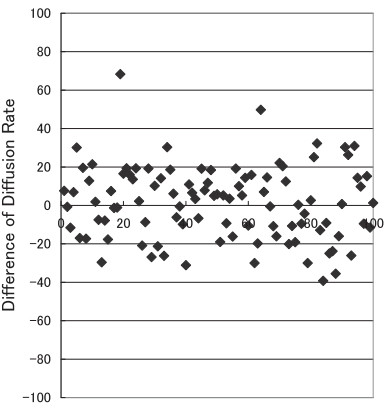

(b) KE-1 model

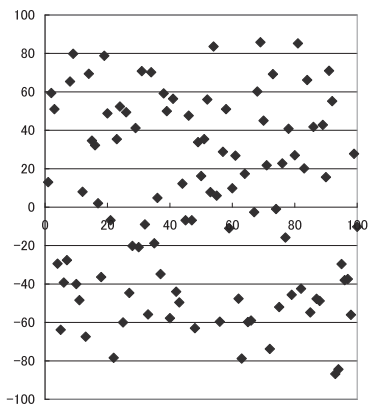

(d) BA model

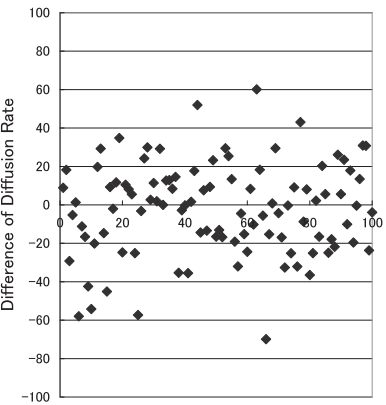

(f) KE-2 model
Fig. 2 Difference of diffusion rate (condition 1)

\section{3 実験 1 における非均質性の影響に関する考察}

Table 4 に拈いて, 条件 1 3 の各ネットワークモデルで サービス 1 とサービス 2 の普及率を比較すると, 各サービス の条件が等しいため平均普及率に差はなかった。また各ネッ トワークモデルにおいて, 条件 1３の普及率を比較すると， どのネットワークモデルにおいても消費者効用が均質である 条件 1 の普及率が一番高く, 消費者効用の非均質性が大きい 条件 3 の普及率が一番低くなっていた。

Fig. 3 は条件 1 3 の普及過程の一例をグラフにしたもの である。紙面の都合上，WS モデルのみを示すが他のネット ワークモデルにおいても以下に示すのと同様の傾向が得られ ている. シミュレーションステップ $t$ の小さいシミュレーショ ンの初期においては, 消費者効用の非均質が大きい条件 3 の グラフの傾きが最も大きく，他の条件より購入者が増えてい るようすが見られる。これは，消費者効用の非均質性が大き い条件ほど期待効用 $R_{i m}^{e x p}$ が大きい消費者が存在し，それら の消費者が早期に購入する可能性があるためである。しかし
満足度関数 $(10)(11)$ 式から, 期待効用 $R_{i m}^{e x p}$ が大きい消費者 は購入後満足しにくく，また満足より不満足による影響のほ うが大きくなるため，消費者効用の非均質性が大きいと外部 性の効用 $y_{i m}^{j}(t)$ が小さくなりやすい. 加えて期待効用 $R_{i m}^{e x p}$ が小さい消費者は購入しにくいこともあり，消費者効用の非 均質性が大きいと購入が広がりにくく，シミュレーションの 後半においてグラフの収束が早くなり，結果として普及率が 低くなったと考えられる，このような傾向は，ほかのネット ワークモデルの普及過程においても確認された.

また消費者効用が非均質である条件 2 と条件 3 を比較する と，どのネットワークモデルにおいても非均質性が大きい条 件 3 のほうが普及率が低くなっていたことから，消費者効用 の非均質性が大きくなるにつれ，早期購入者が増えるという 普及におけるメリットよりも購入が広がりにくいというデメ リットの影響が強くなっていると考えられる。

\section{4 実験 2 における非均質性の影響に関する考察}

Table 5 においてサービス 1 とサービス 2 の普及率を比較す ると, 条件 4〜6のどのネットワークモデルにおいても, サー ビス 1 より消費者効用のばらつきが大きいサービス 2 のほう が普及率が高くなっていた。

Fig. 4 のグラフは，条件 5 の普及過程の一例を表わしたも のである。紙面の都合上，Fig. 3 と同様にWS モデルのみを 示すが，他のネットワークモデルにおいても以下の傾向は同 様である，消費者効用が非均質であるサービス 2 のほうがシ ミュレーションの早期において購入者が多く，そのまま普及 率の差が広がり，最終的にサービス 2 の普及率のほうが高く なっているようすが見られる，この傾向は，他のネットワー クモデルや条件 4, 6 の普及過程においても確認された.

本稿における普及モデルは, 購入者からの外部性の効用 $y_{i m}^{j}(t)$ にってつながりをもつエージェントが購入を行ない, 普及が進んでいくモデルとなっている，また今回の普及モデ ルでは，消費者はどちらか一方のサービスを選択して一度だ け購入し，その後買い替えなどは行なわない，そのため消費 者効用の非均質性の影響で早期購入者が多くなることが競合 においては有利に働き，一度普及率に差がつくと，そのまま シミュレーション終了までサービス 2 の普及率のほうが高く なっていたと考えられる.

しかし Table 5 における各条件のネットワーク全体の普及 率を見ると，どのネットワークモデルにおいても条件 $4>$ 条 件 $5>$ 条件 6 の順に普及率が高く，両サービスの効用の非均 質性が大きくなるほどネットワーク全体の普及率が低くなっ てしまうようすが見られた。これは実験 1 と同様に，効用の 非均質性が大きいほど，早期の購入者は多くなるが，その後 購入が広がりにくくなるためだと考えられる，以上のことか ら，消費者効用の非均質性による影響として，非均質性が大き いサービスほど競合相手に勝つことはできるが，ネットワー ク全体への普及率は下がってしまうことが明らかになった。

また Table 5 において条件ごとにサービス 1 とサービス 2 の普及率の差を比較すると，どのネットワークモデルにおい 


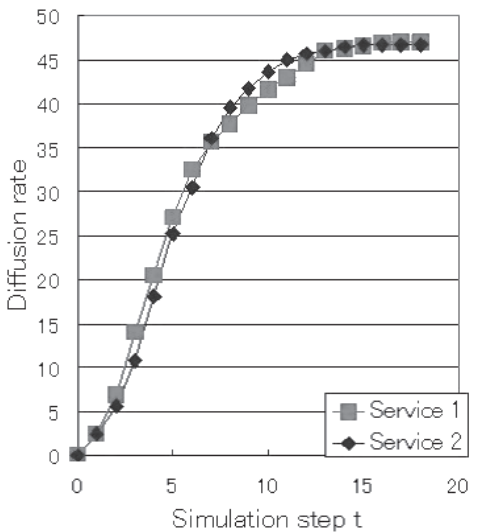

(a) Condition 1

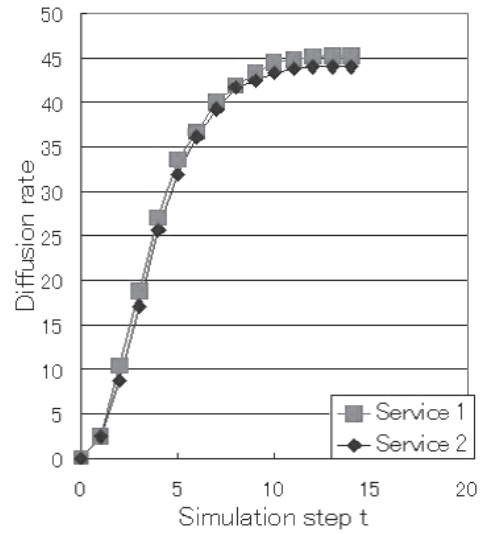

(b) Condition 2

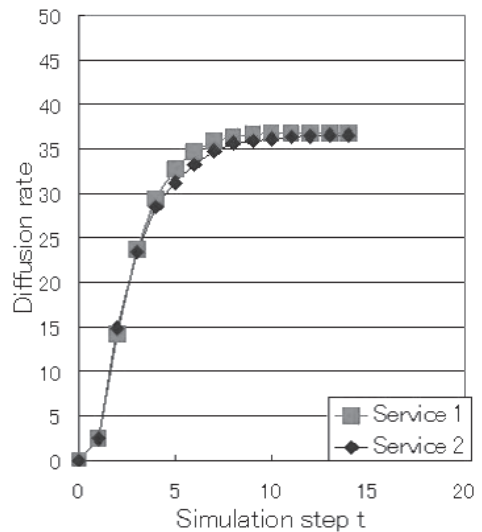

(c) Condition 3

Fig. 3 Diffusion process (WS model)

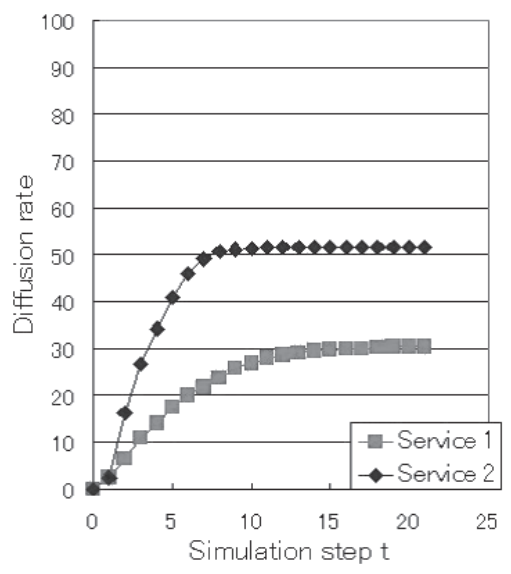

Fig. 4 Condition 5 (WS model)

ても条件 $5>$ 条件 $4>$ 条件 6 の順に差が大きくなっていた. 条件 5 に扔ける普及率の差が一番大きいのは, サービス 1,2 の消費者効用の非均質性の大きさの差が一番大きい条件であ るためだと考えられる. また条件 4 のほうが条件 6 よりも普 及率の差が大きいことから, 両サービスの消費者効用の非均 質性の大きさの差が同じ場合, 各サービスの非均質性が小さ いほうがその差による影響が表われやすいと考えられる。

\section{4. 結言}

本稿では，一度契約すると継続的に利用し続け再選択不可 能なサービスを対象として, 複数のサービスが競合する市場 に扔いて消費者効用の非均質性が普及にどのような影響を与 えるのかを検証するために, マルチエージェントシステムと 複雑ネットワークを用いて, 消費者の購買行動モデルと情報 伝播の消費者間ネットワークモデルを提案した.

計算機実験を行なった結果から，ネットワーク構造の平均 頂点間距離とクラス夕係数が普及率に影響を与えることがわ かった。 また，消費者効用の非均質性が大きいとネットワー ク全体への普及率が低くなってしまうことがわかった。しか し競合するサービス同士の性質が異なる場合, 全体への普及
率は低くなってしまうものの，消費者効用の非均質性が大き いサービスのほうが相手サービスより普及することも明らか になった。

今後の展望としては, 繰り返し利用し再選択可能なサービ ス普及モデルへとモデルを拡張し，消費者の買い替え行動な ども考慮したサービス普及研究への展開などが考えられる。

\section{参 考 文 献}

1）サービス産業のイノベーションと生産性に関する研究会：サー ビス産業に强けるイノ゙ーションと生産性向上に向けて 報 告書 $(2008)$

2) O.K. Mont: Clarifying the Concept of Product-Service System, Journal of Cleaner Production, 10-3, 237/245 (2002)

3) J. Bailey, J. Spohrer, P.P. Maglio and D. Gruhl: Steps toward a Science of Service System, IEEE Computer, 40-1, $71 / 77$ (2007)

4) 下村, 原, 渡辺, 坂尾, 新井, 冨山：サービス工学の提案一第 1 報 サービス工学のためのサービスのモデル化技法, 日本機 械学会論文集 C 編， 71-702, 315/322 (2005)

5) R. Wolak, S. Kalafatis and P. Harris: An Investigation into Four Characteristics of Services, Journal of Empirical Generalisations in Marketing Science, 3, 22/41 (1998)

6）宮田, 池田：ネットが変える消費者行動 クチコミの影響力の 実証分析, NTT 出版 (2008)

7) M.L. Katz and C. Shapiro: Network externalities, competition, and compatibility, American Economic Reviews, 75-3, 424/440 (1985)

8）川村, 大内：ネットワーク外部性の働く製品市場のモデル化と プレゼント戦略の評価, 日本オペレーションズ・リサーチ学会 和文論文誌，48, 48/65 (2005)

9）江田, 藤井, 貝原: 複雑ネットワーク環境に扔ける消費者の異 質性を導入した外部性を有する製品普及に関する研究，計測自 動制御学会論文集，45-11，605/611 (2009)

10) N. Fujii, T. Kaihara and T. Eda: Agent-based Simulation of Product Diffusion with Network Externality in a Heterogeneous Consumer Network, Journal of Advanced Computational Intelligence and Intelligent Informatics (JACIII), 15-2, 173/179 (2011)

11) N. Fujii, T. Kaihara and T. Yoshikawa: Multiagent System-based Simulation of Service Diffusion in Consumer Networks-Introducing Heterogeneity into Consumer Utility-, International Journal of Organizational 
and Collective Intelligence (IJOCI), 2-1, 49/62 (2011)

12）吉光, 新井, 下村, 原 : サービス工学に基づくサービス CAD

システムの構築（第 28 報）一プロスペクト理論に基づいた受 給者視点のサービス評価一, 2006 年度精密工学会秋季大会学 術講演会講演論文集，91/92 (2006)

13）増田, 今野: 複雑ネットワークの科学, 産業図書 (2005)

14) P. Erdős and A. Rényi: On Random Graphs, Publicationes Mathematicae, 6, 290/297 (1959)

15) D.J. Watts and S.H. Strogatz: Collective Dynamics of 'Small-World' Networks, Nature, 393, 440/442 (1998)

16) A.L. Barabási and R. Albert: Emergence of Scaling in Random Networks, Science, 286, 509/512 (1999)

17) K. Klemm and V.M. Eguíluz: Highly Clustered Scale-free Networks, Physical Review E, 65, 036123 (2002)

18) K. Klemm and V.M. Eguíluz: Growing Scale-free Networks with Small World Behavior, Physical Review E, 65, $057102(2002)$

19) E.M. Rogers: Diffusion of Innovations, Free Press (1982)

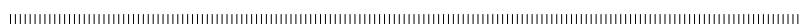

[著 者 紹 介 $]$

藤 井 信 忠 (正会員)

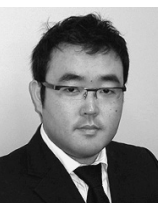

1998 年神戸大学大学院自然科学研究科博士前期 課程修了. 神戸大学工学部助手, 東京大学人工物 工学研究センター助手, 客員准教授, 神戸大学大 学院工学研究科准教授を経て, 2010 年 4 月より神 戸大学大学院システム情報学研究科准教授となり 現在に至る. 博士 (工学). 人工システムの構成論 的アプローチに関する研究に従事. 日本機械学会, 精密工学会, システム制御情報学会などの会員.

\section{貝 原 俊 也（正会員）}

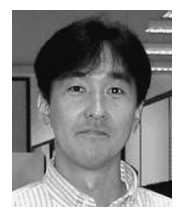

1985 年京都大学大学院工学研究科修士課程修了. 三菱電機 (株), 神戸大学大学院自然科学研究科助 教授, 大学院工学研究科教授などを経て 2010 年 より神戸大学大学院システム情報学研究科教授と なり現在に至る。社会的マルチエージェントシス テムの理論と, その生産・流通・社会システムなど への応用に関する研究に従事. Ph.D. (University of London). 日本機械学会, 日本 OR 学会, 精密 工学会, ISCIE, IFIP, IEEE などの会員.

\section{吉川智 哉}

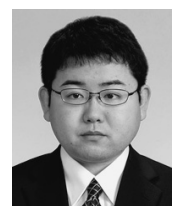

2009 年神戸大学工学部情報知能工学科卒業. 2009 年神戸大学大学院工学研究科情報知能学専攻 入学. 現在に至る。マルチエージェントシステム と複雑ネットワークを用いたサービス普及シミュ レーションに関する研究に従事. 精密工学会の学 生会員. 